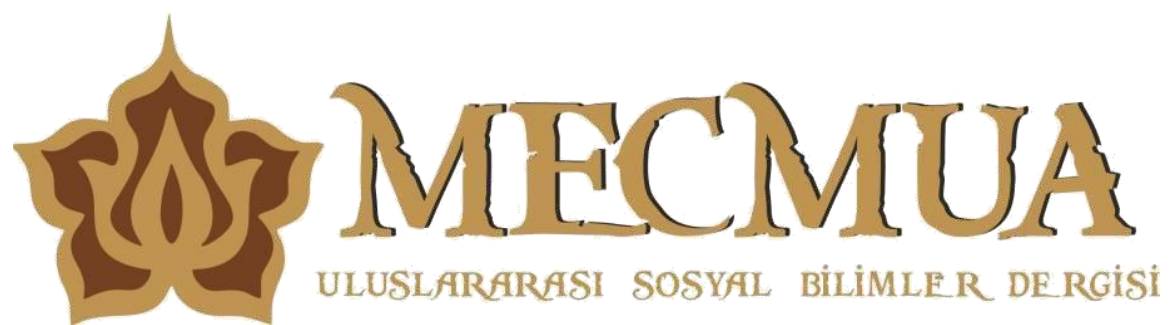

Güz 2019, Yıl: 4, Sayı: 8, ss. 1-23

Doi Number: 10.32579/mecmua.532299

Araştırma Makalesi / Research Article

$\underline{\text { Yayın Süreci / Publication Process }}$

Yükleme Tarihi: 25.02.2019 / Kabul Tarihi: 18.09.2019

\author{
Cemile Arzu AYTEKİN*
}

Aşsıın BAHADIR ${ }^{* *}$

\title{
BEN VE ÖTEKI'NE YOLCULUK İKİLİĞİ BAĞLAMINDA, BELLEK OTOPORTRELERI KARŞILAŞTIRMASI: ANDY WARHOL VE GUSTAVE COURBET OTOPORTRELERİ
}

\begin{abstract}
ÖZ
Bellek her zaman geçmişten bugüne bir akışı gösterir ve durağan değildir. Bunun sayesinde de insanın bilinçli varlığının öz'ünü, insan bilincini kuran da bellektir. Bellek otoportrelerinde de insanın bilinç ve bilinçaltı verilerinin yansımalarını bulabiliriz. Ben ve Öteki'ne yolculuk ikiliği bağlamında da iki ayrı örnek üzerinde kişisel bellekle ve dolayısı ile toplumsal bellekle de ilintili yönelimleri bulabilmekteyiz. Bu araştırmada amaç; Ben'e ve Öteki'ne Yolculuk İkiliği Bağlamında, Kendine Yaklaşma (Ben-leşme) ve Kendinden Uzaklaşma (Ötekileşme) olarak karşıt uçlarda iki bellek otoportresini, Andy Warhol ve Gustave Courbet otobiyografik sanatsal anlatımlarını (özne-anti özne), karşılaştırmalı analizler yolu ile incelemektir. Bu bağlamda, araştırmada öncelikle ben ve öteki kavramları psikolojik ve felsefi açıdan incelenmektedir. İki sanatçının örnekleme alınan otoportreleri, otobiyografik açıdan edinilen bilgiler 1şı̆̆ında karşılaştırmalı analiz edilerek benleşme ötekileşme unsurları saptanmaktadır.
\end{abstract}




\title{
IN THE CONTEXT OF ME AND OTHER JOURNEY, COMPARISON OF MEMORY SELFPORTRAITS: ANDY WARHOL AND CUSTAVE COURBET SELFPORTRAITS
}

\begin{abstract}
Memory always shows a path from the past to the present and is not static. Thanks to this, the essence of conscious existence of man is memory and make up the human consciousness. We can also find memory self-portraits and reflections of human consciousness and subconscious data. In the context of the journey to Me and the Other, we are able to find orientations about personal memory and thus social memory on two separate examples. Purpose in this research; Andy Warhol and Gustave Courbet sutudied their autobiographical artistic expression(subject-anti subject) by comparative analysis. In the context of the duality of a journey to me and the other, they exhibited their self-portraits of memory in two opposite directions as getting closer to oneself(individualism) and alienation from oneself(marginalization). In this context, firstly I and other concepts are examined in terms of psychological and philosophical aspects. Selected self-portraits of two artists, In the light of autobiographical information, comparative analysis and me and other elements are determined.
\end{abstract}

Keywords: Me, Other, Andy Warhol, Gustave Courbet, Autobiography, Memory Selfportrait

\section{Giriş}

Araştırmada, ben ve öteki kavramları, felsefi ve psikolojik bakımından irdelenmekte, Gustave Courbet ve Andy Warhol otobiyografilerinden ve iki farklı döneme ve yaşantıya ait bellek otoportresinden yola çıkarak sanatçıların ortaya koydukları otoportreler üstünde, Kendine Yaklaşma (Ben-leşme) ve Kendinden Uzaklaşma (Ötekileşme) kişisel ve toplumsal bellek çözümlemeleri yapılmaktadır. Bu bağlamda, Ben ve öteki kavramını İspir ve Küçükalkan şu şekilde açıklamaktadır: "Ben ve öteki, varlığın parçalanması anlayışını ve varlıktaki metafizik birliği göz ardı etmenin bir sonucu olarak, "ben"in ve başka bir "ben"in arasındaki ayrılığa işaret eder"(İspir ve Küçükalkan, 2013: 2). Yani bir kişi veya gruptan farkl1lık gösteren kişi yada grup öteki olarak kabul edilmektedir. Bu bağlamda, otobiyografiler incelenerek, benleşen ve ötekileşenler saptanmaktadır.

Otobiyografi kavramı; kişinin hayat hikayesinin tamamının kendisi tarafından kaleme alınmasıdır. Otobiyografi, yazarının benliğini ortaya koyarken aynı zamanda bu benliği oluşturan çevresel faktörleri de ortaya koymayı sağlamakta ve anımsamayı merkezine almaktadır. Bu bağlamda otobiyografi; yazarın kimliğinin oluşmasında etkili deneyimlerinin yazınsal olarak ifade edilmesidir(Büyüktuncay, 2014). Bir edebiyat alanı olan otobiyografinin görsel sanatlar için de büyük önemi bulunmaktadır. Çünkü, iç dünyaya yolculuk olan görsel sanatlarda, sanatçılar bir eseri ortaya koyarken özyaşamsal deneyimlerinden yola çıkarak sanatlarında bir 
anlatım oluşturmaktadır. Bu noktada eserin içeriğinin çözümlenebilmesi için sanatçı otobiyografisine başvurmak gerekmektedir. Bu bağlamda araştırmada karşılaştırma yapilacak Andy Warhol ve Gustave Courbet otoportrelerinde benleşme ve ötekileşme unsurlarını ortaya çıkarabilmek amacı ile sanatçı otobiyografilerine ve kişisel bellek unsurlarına başvurulmuştur.

$\mathrm{Bu}$ bağlamda, Araştırma problemi ile ilgili verileri toplamak için ilgili literatür taraması yapılmıştır. Araştırma nitel araştırma özelliği taşımasından dolayı, tarama modelleri kapsamında belgesel tarama modelindedir. Belgesel tarama yolu ile ilgili görsel ve yazılı kaynaklara-sanatçıların kişisel deneyimleri ile dolu, kitap, günlükler, notlar, röportaj metinleri vb. yani sanatçıların kendilerini anlattıkları bir takım dokümanlarına ulaşılmakta, elde edilen bilgiler doğrultusunda, örneklemde kullanılan eser görselleri üzerinde, bellek, ben ve öteki, özne-anti özne kavramları ışı ğında biçimsel ve içeriksel analizler yolu ile karşılaştırmalı yorumlamalarda bulunulmaktadır.

\section{Ben ve Öteki Kavramları}

Bir ötekinin oluşabilmesi için öncelikle bir ben'e ihtiyaç vardır. Beni ben yapan öteki, ötekiyi öteki yapan ise ben'dir. Ben kavramı Tdk Türkçe sözlükte "bir kimsenin kişiliğini oluşturan temel öğe, ego" olarak tanımlanmaktadır(Tdk, 2012). Lacan, 1995 yılında, öznenin erken bebeklik döneminde arzu deneyimi yaşadığından bahsetmektedir(Layikel, 2006). Bilinç öncelikli olarak hayvani istekleri olan bir haldedir. Merkezinde yaşama dürtüsü bulunmaktadır. Bu noktada, ben'in yüzleştiği ben olmayan doğal bir nesne şeklindedir. Hayvani şekilde olan ben varlık için yeterli değildir. Bu nedenle, ben'i arzulayan başka bir ben gerekmektedir(Apaydın, 2006).

$\mathrm{Bu}$ durumu Lacan, annenin bebeğe hayranlıkla bakmasını ve bebeğin bunu hissederek kendi varlığını anlaması olarak açıklar ve buna 'ayna evresi' adını vermektedir. Benliğin oluşumunda en önemli dönem bu dönemdir. Bununla bağlantılı olarak, özne yaşamı boyunca arzulanmayı isteyerek söz konusu olan annesindeki hayranlık bakışını isteyecektir(Layıkel, 2006). Lacan özneyi tanımlarken çıkış noktası olarak, yoksunluk, boşluk gibi negatif kavramlarla, bilinçdışının öznesini oluşturmaktadır.

"Yanlış ve çarpık bilinçliliğe demirlenmiş, klâsik ideoloji kavrayışının gözden geçirilmesini olanaklı k1lan etkilerin en önemlilerinden biri Lacan'dan, Lacan'ın öznesinden, gelir. Çünkü, Lacan'ın ardılı olan düşünürlerin(başta Althusser olmak üzere) onun yeniden içeriklendirdiği bilinçdışı kavramına başvuruları, ideoloji eleştirisini ve çözümlemesini, bilinç ve bilinçdışı arasındaki ilişkiye odaklamıştır. $\mathrm{Bu}$ yöndeki ideoloji eleştirisinin öznesi, en genel anlamıyla söylenirse, kendi bölünmüşlüğ̈̈nü(divided), yarılmışlığını (split) ve eksikliğini(lack), ancak ideolojik bir fantezi boyunca gidermeye çalışan bir öznedir"(Dursun, 2004: 184).

Ben, benliğin ve kişiliğin içinde gizlenen bir ev gibidir. Özne kendini benliği ile mevcut kılmaktadır. Benlik çevreyi algılayarak özümsediğimiz şeydir. Jung’a göre "Ben, son derece karmaşı bir yüceliktir, verilerin ve duyumların birikimi ve yoğunlaşmasıdır"(Jung, 70; Şahin, 2010; 25'deki alıntı). Öznenin kendiliğini oluştururken merkez konumunda yer alan ben, aslında öteki'ni de içermektedir. Bu bağlamda ben ve öteki diyalektiği varoluşu oluşturan bir gereksinimdir. Ben varlığı var eden yerdir. Fakat, özne kendini kötü ötekinin altına verdiğinde ben-öteki 
arasında savaşlar başlar. Öteki ile ilişkisini de kesmesi söz konusu değildir. Çünkü, benliğini devam ettirmesi için iletişime ihtiyacı bulunmaktadır. Ayrıca, ben öteki tarafindan her saldırıya uğradığında benliğinde bir parçalanma gerçekleşmektedir(Şahin, 2010).

"Kişilik parçalanması, ötekileşmenin en ileri safhasıdır. Bireyin, kendi öz benine ötekileşmenin sonucunda birey parça parça kişilik ve kimliklere bürünür. Bürünmüş, olduğu bu kimlikler, birbirinden bağımsız ayrı ayrı fertler konumundadır. Aynı zamanda kişi parçalanma sonucunda meydana gelen, yani öz benlikte ortaya çıkan yeni kimliklere hayretler içinde bakar. Hayret ilerledikçe, birey kendine yabancılaşır. Ne yaptığını bilmez hâle gelir’'(Şahin, 2010: 29-30).

Kendilik psikolojisinin temellerini 1950'li y1llarda atan Kohut'un, 'kendilik nesnesi' kavramı önemli bir yere sahiptir. Ona göre, kendiliğin, yani kişiliğin özünü meydana getiren ikizlik, aynalanma ve idealizasyon gereksinimlerini barındıran narsistlik arzularının küçük yaşlarda önce tatmin edilmesi ve zaman içinde hayal kırıklığına uğratılması önemli bir yere sahiptir. Bu süreçte, narsist açıdan var olan arzuların fazla ya da eksik tatmin edildiği bir deneyim gerçekleşirse, özne varlığını devam ettirmek için bir 'kendilik nesnesi' ile ilişki kurması gerekmektedir. Kısacası, ilişki kurulan nesnenin yani ötekinin, kişinin kendisini var etme aracına dönüşmesi söz konusudur. 1970'li yıllara gelindiğinde ise, insan zihnini yalıtan Kartezyen düşünceye karşı olarak öznelliklerarası düşünceler öne çıkmaya başlamıştır. $\mathrm{Bu}$ düşünceler, insan zihninin erken dönemlerinden itibaren deneyimlediği karşılaşmaları, ilişki içerisine girdiği durumları içselleştirdiği bir süreçle meydana geldiğini savunmaktadır. Bu bağlamda daha önce de söz konusu olduğu gibi, öteki olmadan bir ben söz konusu olamaz. Zihinsel süreçte oluşan benlik zorunlu olarak öteki ile ilişki halindedir(Layıkel, 2006).

Ötekilik kavramı, milliyet, sınıf, cinsiyet, meslek, inanç vb. sınıfsal ayrımların gerçekleşmesiyle meydana gelmektedir. Bütünleşme ve farklılık insanın varoluşsal ve kimliksel eğilimleridir. Kimliğin önemli bir yapıtaşı olan aidiyet duygusu, biz’i tanımlarken ortak yönleri tanımlamakta, ötekileri tanımlamak için ise farklılıkları keşfetmektedir. Böylelikle, biz ve ötekiler konumlanmış olacaktır. Benliğin öteki üstünden biçimlendirilmesinde ötekinin doğası gereği bene göre olumsuzluk bulundurması, bazı konuları öne çıkartır. İlk olarak özne kendisini öteki ile açıklar. Öteki, özne için negatif olanı anımsatır ve bu karşıtlık kimliğinin kavranmasını daha basit hale getirir. Ayrıca, özne ötekinin varlığı ile kendi içindeki kötülüklerinden kurtulur, öteki üstüne giydirdiği kötülüklerle kötülükleri de kendisinin uzağında konumlandırmış olur ve bu sayede kendisini rahatlatmaktadır(Karaduman, 2010). Ötekileştirme altı ana başlık altında toplanabilmektedir:

“1- Cinsiyete bağlı olarak öteki

2- Etnik Kimliğe bağlı olarak öteki

3- Dini kimliğe bağlı olarak öteki

4- Coğrafi kimliğe bağlı olarak öteki 
5- Ekonomik kimliğe bağlı olarak öteki

6- İdeolojik kimliğe bağlı olarak öteki

Bu yukarda belirttiğimiz tarzlarda ötekinin ortaya çıkısını gündelik yaşam içerisinde, toplumsal ilişkilerde, uluslararası ilişkilerde ve daha birçok alanda görebiliriz"(Temizkan, 2011: 78).

Ben olmayanın, yani ötekinin itici olması, aslında onun korkulan olmasının sebebi onun bir arzu nesnesine dönüşmüş olmasından kaynaklıdır. O kaçılan fakat bir taraftan ulaşılması gerekli olandır. Modern dönemde öteki, ikircikli bir yapıya bürünmeyle birlikte kendine sayg1 ya da isyan etme sebebi de olabilmektedir(Temizkan, 2011).

Öteki kavramını anlamak adına, psikoloji alanı önemli olduğu kadar düşünsel diğer yaklaşımlar bakımından da önemlidir. Bu bağlamda, öteki konusunun felsefi açıdan incelenmesi konusunda Kierkegaard, Heidegger, Sartre ve Levinas gibi varoluş̧̧u düşünürler öne çıkmaktadır.

\section{20. Yüzyıl'da Ben'e ve Öteki'ne Yolculuk İkiliğine Düşünsel}

\section{Yaklaşımlar}

Geleneksel toplumlarda, 20. Yüzy1l'da başlayıp günümüzde devam eden şekilde bir kimlik sorunu bulunmamaktadır. Ancak, 19. Yüzyıldan başlayarak toplumsal açıdan başlayan çözülme ile bireyselleşme ön plana çıkmaya ve bireysel kimlik duygusu ortaya çıkmaya başlamıştır. 19. Yüzyılda gerçekleşen bu bireysellik duygusunun nedeni olarak modernite gösterilebilir. Çünkü, modernite, bireyselliği savunmakta ve bireyin kendine has karakterine vurgu yapmaktadır(Karaduman, 2010). Modernite ile özgürlük, akıl, birey, insan hakları, eşitlik ve demokrasi gibi düşünceler kendisini göstermeye başlamış ve din, felsefe sanat ve bilimin sınırları ayrılmıştır.

Modern dönemin temel arzusu, belirsizliği ortadan kaldırarak her şeyi belirgin hale getirmektir. Bu bağlamda, modernitenin kesinliğe verdiği önemle bağlantılı olarak öteki bir düşman sınıflandırmasında yer almaktadır. Çünkü, öteki hiçbir şey olmadığı gibi, her şeydir. Modernitede bireyin kimliğinin oluşumunda öteki temel motivasyonu sağlamaktadır. Kimliğin oluşumunda, ben'e etiketlenen her şey ötekiyi'de oluşturmaktadır. Modernitenin istediği anlamda ben'in kesin sınırlarını çizmek için mutlaka bir öteki'ye ihtiyaç vardır. Çünkü, ikisi de birbiri ile açıklanmaktadır. Öteki tanımlanırken, biz ve onlar diyalektiği bağlamında incelenirken, ayrıca varoluş, etik ve psikolojik açılardan da incelenmektedir. Ötekinin saptanmasında oldukça fazla soru vardır. Ben ve öteki kavramlarının daha derinlemesine anlaşılabilmesi için düşünsel açıdan irdelenmesinde fayda bulunmaktadır. Bu doğrultuda varoluşçu düşünürlerin fikirleri değerlendirilecektir. Varoluşçu felsefe açısından incelenmesinin nedeni, sosyolojik bakımdan, ilerlemeler yaşanan dünyada 18. ve 19. Yüzyıl'da bireyin umutlarına karş1lı bulamayarak, 20. Yüzyıl'a bunalımlarla girmesidir. 20. Yüzyıl ise savaşlarla birlikte bunalımlar iyice 
artmış, birey 'ben' olarak varoluşçu düşünürler tarafından ele alınarak savunulmuştur(Temizkan, 2011).

Öncelikle, Levi-Strauss Yapısal Antropoloji araştırmasında, benlik ve öteki konusunda birbirlerini açıklamak adına ikizlik ilişkisinden söz etmektedir. Bu ilişki kötücül bir yaklaşımdır. Şöyle ki, öteki bir nesne gibi deneysel olarak anlanabilecek bir kavram olarak ele alınmıştır. Ötekinin ne olduğundan çok ne olmadığı ile ilgilenilmiş, yani modernden uzak ve farklı bakış açısı ile tanımlanmaya çalışmıştır. Kısacası, öteki modern olmayandır. Modernizm için kesinliklerle temellendirilen öteki, postmodernistler için ise kurmaca olan öznenin karşılığı olarak yer olmaktadır(Temizkan, 2011). Zygmunt Bauman, modern dönemde ben ve öteki karşıtlığ 1 yaratılarak öteki üstüne dayatmalarda bulunulduğundan söz etmektedir. Bauman, ortaya koyduğu metinlerinde öteki için yabancı kavramını kullanarak incelemiş ve bunun küreselleşen çağda etkisizleştiğinden söz etmektedir(Başer, 2011).

Kierkegaard'a göre; birey kendisini tanırken ötekini de tanımaktadır. Yani bu kendi ben'ini oluştururken aslında otomatik olarak öteki'nin benliğini de oluşturmaktan başka bir şey değildir. Onun felsefesinde ötekiyi sevme, ona karşı bencil davranmama ve ilişkide bulunma şeklinde bir yaklaşım bulunmaktadır. Ayrıca, insanlar tanrıya olan sevgiden dolayı ötekiyi de sevmelidir(Çelebi, 2008). Bu Mevlana Celaleddin-i Rumi'nin 'yaradılanı sev yaradandan ötürü' düşüncesi ile benzer bir düşüncedir.

Öz ve varoluş arasındaki tartışma, Klasik felsefe ve varoluşçular arasında en büyük tartı̧̧ma konularından bir tanesidir. Klasik felsefede öz varoluştan önce gelirken, varoluşçularda varoluştan sonra öz gelmektedir. Bu bağlamda, öteki insanın varoluşunda etkisi olmayan bir varlıktır. Bu konuda, Schopenhauer'ın insan kendisinin tasarımıdır düşüncesinde olduğu gibi Heidegger'de bunu dasein olarak tanımlamaktadır(Temizkan, 2011). "Öteki, bir varlık olarak, kendi varoluşunu gerçekleştirdikten sonra sahip olduğu özle, 'ben' için bir anlam ifade eder. Dolayısıyla bu anlam, yabancı, düşman, farklı olarak ya da fark edilebilen, iletişim kurulabilen olarak yapılandırılır"(Temizkan, 2011: 60).

Sartre ise düşünsel yaklaşımlarında öteki kavramını özgürlük üstünden değerlendirmektedir. Bireyin kendini bulabilmesi ve kendini gerçekleştirebilmesi için en önemli şey özgürlüktür ve ötekinin varlığı buna engeldir. Sartre ötekini ben olmayan ben olarak tanımlamaktadır. Ona göre, ben ile öteki arasında bağ hiçlik ile kurulmaktadır. Bu hiçlik her iki taraf için de karşıtlık oluşturmaktadır. Ayrıca, öteki ile bağ kurulduğunda utanç duyulmaktadır. Çünkü, insan ötekine benzediği için utanmaktadır(Temizkan, 2011). "Başkası hem varoluşum, hem de kendimi bilişim için gerekli. Nitekim, benliğimin tanınması, içerimin ortaya çıkarılması başkasının da tanınmasına; beni düşünen, bana karşı ya da benim için bir şeyler isteyen bir özgürlük olarak onun da ortaya çıkarılmasına yol açıyor. Bundan sonra, "öznelerarası" adını vereceğimiz bir evren buluyoruz karşımızda. İşte bu evren içindedir ki insan kendinin ve başkalarının ne olduğunu anlıyor"'(Sartre, 1985: 85).

Levinas'ın öteki kavramını ile ilgili düşünsel yaklaşımlarında öteki’yi ulaşılamaz ve 
açıklanamaz olan başkalık şeklinde tanımlamaktadır. "Levinas'a göre Batı felsefesi, aynı'nın, bir diğer ifade ile özne kabul ettiği 'ben'in bilme ve kavrama ilişkisi ile farklılıklara bakmasından dolayı, etiğin birincil rolünü göremez. Bu bilme ve kavrama gücü ile anlamlandırılan dünyada, farklı ve yabancı olan, yani öteki olan ya ben'e benzetilir ya da ben'in temsil gücüne mahkûm edilir. Böylesi bir durumda, farklı olanın farklılığ ile varolma sansı kalmaz. Bunun sonucunda da ya ötekinin farklılığı, ya da direk kendisi, varlığı yok edilir”'(Temizkan, 2011: 71). Levinas ötekiyi anlamaya çalışmanın ve onu değiştirmeye çabalamanın, ötekinin ben'ine müdahale ederek aynı'nın içine mahkum etmeye çalışmak olduğunu savunmaktadır. Bilmek ve anlamanın ise ötekiyi benin egemenliği altına sokmak olduğundan söz etmektedir. Bu ben ile ötekiyi aynı hale getirmektir(Temizkan, 2011).

Postmodern dönemde ideolojik açıdan tasarlandığı şekilde 'eksikliğin öznesini' ötekine gereksinim duyan özneyi anlamak için, Hegel'in 'kendilik bilinci' yaklaşımının incelenmesi gerekmektedir. Öteki ilişkisi oluşturabilen düşüncenin öznesinin çıkış noktası kendilik bilincidir.

"Hegel, kendilik bilincinin ne olduğunu, bilincin ya da Tin'in dünyayı bilmek için ilerleyişinin, kendimizi anlamak bakımından hangi olanakları sunduğunu, Phenomenology of Spirit'te tartışır. Bu, Tin'in kendisine nasıl göründügünün, Mutlak olanın nasıl gerçekleştiğinin ve görünüşün(fenomen) töz (substance) ile ilişkisinin çalışıldığı bir metindir. Tin'in, farklı bilinç biçimlerini aşama aşama geçerek, daha gelişkin bilinç biçimlerine doğru yönelmesiyle mutlak bilme hâline geldiği bu yapıt, Butler'ın söylediği gibi, sadece yolculuk eden bilince dair bir anlatı değildir. Yapıt, bu yolculuğun ta kendisidir(Butler, 1987: 21). Yolculuğu boyunca Hegel'in öznesi, sadece deneyimlediklerinden öğrenen ve bu bakımdan da sonsuz kapasitesi olan bir öznedir. Öyleyse Hegel'in düşünce sistemi, kendisini bilebilmek için bir etkinlik içine giren Tin'i, yani bilinci/özneyi kuramlaştırır. Bu kuramlaştırma, bilinçten kendilik bilincine (self cosnciousness) doğru ilerleyiş̧in diyalektiğini ve tarihini gözler önüne serer”(Dursun, 2004: 184).

Öncelikle Hegel'de özne ve nesne arasındaki bağlantı, bir dolayımlama bağlantısıdır. Özne, mutlak varlığa veya hakikate sahip olmak için, kavramın kendisini somuta doğru açılımladığı bir süreçtir. Ben olarak kendini, ötekini tanıyarak gerçekleştirmektedir. Bu tanımada ilk olarak kendi bilincini algılar. Ben'in bilincine kendisi üzerinde düşünmesi ile varabilir. Bu, öznesi kendi kendine yolculuk eden bir özne demektir. Bu yolculuk zor bir yolculuk olmakla birlikte, kolay şekilde kendi bilincini kavraması mümkün değildir. Bilinç, benliğe ulaşmak için her aşamada kendisinin karşısına kendisini çıkarmak durumundadır. Kendisine varmak için bilinç, bir başka ben'e, yani ötekine ihtiyaç duymaktadır. Ötekilik, beni keşfetmek için çıkılan bu yolculukta, bilinç tarafından kendilik bilincine gelirken ortaya çıkmaktadır. Kısacası, Hegel'de ben'lik ve öteki'lik bilme türü olarak oluşmaktadır. Hegel'e göre bir şey bilinç tarafından kendisinden ayrılıyorsa olumsuz birşeydir, yani öteki bilinç tarafindan ayrıldığı için olumsuzdur(Dursun, 2004). Kendilik bilinci bu olumsuzlamayı yaparak, bilinci ve dünyadaki ontolojik farkı yok etmek amacıyla bunu yapmaktadır. Ayrıca, kendilik bilincinin, öteki'yi ayırmasını da Hegel şu şekilde açıklamaktadır: 
"Kendimi kendimden ayırıım ve bunu yaparak, benden ayrılan şeyin benden farkı olmadığının doğrudan farkına varırım. Ben, kendi aynılığındaki varlık, kendim den kendimi reddederim; ama benden ayrı olarak ya da benzemez olarak konulan şey, dolaysız olarak, ayrılmışlığı içinde, benden bir ayrılma değildir'(Hegel, 102; Dursun, 2004: 188'deki alınt1).

Ben ve öteki diyalektiğini tanıma olarak açılayan Hegel, efendi köle ilişkisini anlattığı bölümde ortaya koymaktadır. Tanıma, kendilik bilincinin karşısındakini olumsuz olarak algılamasına rağmen ona olan bağlılı̆̆ını devam ettirdiği anda ortaya çıkmaktadır. Fakat, öteki'ne göre ise kendilik bilinci öteki'dir. Kendilik bilinci, bu nedenle de ötekini olumsuzlamaktadır. Hegel'e göre, ben ve öteki arasında bir bir mücadele bulunmaktadır. Mücadelenin sonucu efendi-köle diyalektiğindeki karakteristik ilişkinin kurulması olarak tanımlanmaktadır. Efendi köle diyalektiği, kendilik bilincinde en büyük eşitsizliğin temsilidir.

"Fark, önceliğe sahip ise, özdeşliğe boyun eğdirilmiyorsa ya da bütüncülleştirmeye yönelik bir amaca zorlanmıyorsa, indirgenemez bir farktır. Hegel, farkı böyle ele almayan ve dolayısıyla da kapanmaya mahkum bir sistem kurmakla eleştirilir çoğu kez (örn; Derrida, Foucault, Butler). Eleştirenler, örneğin; Butler, farkın indirgenemezliğini vurgulamak için, iki tür fark arasında, "diyalektik ve diyalektik olmayan fark" arasında, bir ayrım geliştirir. Diyalektik fark, ki Butler'a göre Hegel'inki budur, ontolojik farkın görünüşlerinden sonra gelir ve daima özdeşliğe yönelir. Bu yönelme, fark ve birlik arasında sonsuz bir salınımdan başka bir şeye yol açmaz. Diyalektik olmayan fark ise, herhangi bir sentetik birliğin içinde asimile olmaya direnendir"'Butler, 1987: 183-184'ten Dursun, 2004: 192). Hegel'de, kendilik bilinci için fark ötekini oluşturmaktadır. Fakat, aynı şekilde kendilik bilinci için bu fark ile kendisini oluşturmaktadır. Görünen, kendilik bilincinden farklıdır. Hakikat ise kendilik bilincinin ben ile tek oluşudur. Dolayısıyla, görünen ötekinin ben'den ayrı varlığı, hakikat ötekinin ben ile tek oluşudur. $\mathrm{Bu}$ birlik parçalanmışlıktır.

"Hegel düşüncesinde varlık biçimine sahip olmayan fark, ancak bölünmüş, bir birlik olarak yani ötekilik içinde varlık biçimi kazanmaktadır. Bu, Hegel'in, ötekinin varoluşunun nedenini görmek bakımından farkın indirgenemez olduğu bir sistem tasarladığını öne süren bir diğer yorumdur"(Dursun, 2004: 192). Kendilik bilinci bir başka ben ile karşılaştığında kendisini kabul ettirme isteğine girmektedir. Bu kendini kabul ettirme isteği kabul edilme arzusudur. Bu diğer ben'e yani öteki'ne kendi benini kabul ettirme arzusudur. Toplumsal olanın da kuruş ilkelerinde aslında bu bulunmaktadır. Bunun sonucunda, bir ben diğer ben'e kendisini kabul ettirir ve efendi olmuştur(Apaydın, 2006).

“Bu çatışmadan efendi kendisini zorla kabul ettirdiği Öteki’yi köleleştirerek, dolayısıyla da ilişkiden tatmin olmadan çıkar. Köle ise, emek yoluyla kendi gerçekliğinin farkına varır, dolayısıyla da özgürleşmeye adım adım yaklaşır. Efendi hiç bir şekilde kendisini arzulayanın arzusundan tatmin olamaz. Çünkü kendisini kabul ettirdiği kişi bir köledir. Ancak köle, efendisinin kendisini köle yaptığının farkına vararak ona karşı çıkabilir”'(Apaydın, 2006: 50-51). 


\section{3. İki Farklı Bellek; Andy Warhol ve Gustave Courbet}

Araştırmada, iki sanatçıya ait bellek otoportreleri üstünde ben'leşme-ötekileşme, özne-anti özne unsurlarının tespit edilebilmesi için öncelikle, Andy Warhol ve Gustave Courbet'in otobiyografileri incelenmektedir.

Andy Warhol, 1928'de Pittsburgh'da hayata gelmiştir. Asıl adı, Andrew Warhola'dır ve Çekoslovakya'lı göçmen bir ailenin oğludur. Warhol, sekiz yaşındayken ciddi bir sinir sistemi rahatsızlığ 1 geçirmiş ve yatalak kalması nedeniyle uzun süre okuldan uzak kalmıştır. $\mathrm{Bu}$ dönemde, sekiz yaşında olmasına rağmen oldukça nitelikli çizimler ve kolajlar yapmış, bu çizim ve kolajlar hayatı boyunca etkisini göstermiştir. 1945 y1lında liseyi bitiren Warhol, sanat eğitimi için Pittsburgh'da Carnegie Mellon Üniversitesi'ne girmiştir. Ailesinin maddi yetersizliğinden dolayı mezun olur olmaz dergilere çizimler yaparak para kazanmak için New York'a taşınmıştır. Bir süre sonra, 'I Miller' adlı ayakkabı markasına yaptığı çizimle onun adının duyulmasını sağlamıştır. Ardından, ilk kişisel sergisini Hugo Gallery'de gerçekleştirir. 1960'11 y1llara gelindiğinde ise, Warhol Pop Art'a yön verecek olan Coca-Cola şişeleri, Campbell's çorba konservelerinin tasarımlarını yapmıştır. Ferus Gallery'de Campbell's çorba kutularını sergilemiş ve 32 çorba kutusunu 1.000 dolara satmıştır. 1963 yılına gelindiğinde, Warhol kendisine ait bir atölye kiralamıştır. Ölümüne kadar üç defa taşınan atölye, Warhol'un fabrikası olarak anılmaktadır. Warhol'un 1966 yllında çektiği film olan Chelsea Girl, ticari salonlarda gösterime giren ilk undergraund film ünvanına sahiptir. 1967'de ise, kapağındaki muz resmi ile üne kavuşan "The Velvet Underground \& Nico" adlı albümü çıkmıştır(Kıvanç, 2014).

1962 yılında açılan sergide, Coca Cola şişelerinden, konservelerden ve dolarlardan sergi mi olur diye büyük tepki almıştır. Bu dönemde şablon olarak serigrafi tekniğini kullanan Warhol, ilk olarak Marilyn'in portrelerini defalarca basmıştır. Onun amacı, dünya çapında bir yıldız ve milyoner olabilmektir. 1963 yılında ise Dean M. Monreo'nun ölümünden çok etkilenir ve eserlerine ölüm teması girmiştir. $\mathrm{Bu}$ bağlamda, kazalar, intiharlar ve elektrikli sandalyeler çalışmıştır. Ölüm teması ilk defa bu kadar renkli olarak ele alınmaktadır. Bu Warhol'un ölüm korkusu ile baş etme yöntemidir. $\mathrm{Bu}$ yıl, Duchamp ile tanışır ve büyük çatı katı bir atölye tutmuştur(Ötgün, 1995).

Resim: 1,

Andy Warhol, Coca Cola, 1962

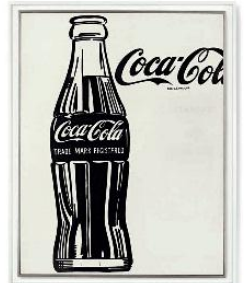

Resim: 2,

Andy Warhol, "theVelvet Underground \&Nico", 1967

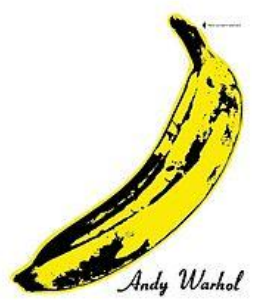

Warhol, sanatın gidişatını tespit etmiş ve bu doğrultuda toplum beklentilerini 
gözlemlemiştir. $\mathrm{O}$, acı çeken bir deha olmamıştır ancak, tüm medya araçlarını sanatı için kullanabilmeyi bilerek sanatını icra etmiştir. Warhol, sanata tüketici toplumun içindeki ilerleyişi göstermiş ve sanatın gidişatında değişimlere neden olmuştur(Kıvanç, 2014).

"Warhol, kapitalist toplumda yaşanan duygusuzluğu resimlerinde yansıtmıştır. Onun resimleri duygusallıktan uzaktır. Warhol, modern toplumda makinenin kazandığ 1 önemi ve gücü simgelemiş, ve kendini makinelerle özdeşleştirmiştir. Seri halde yaptığı baskı resimlerinde görüldüğü gibi içgüdülerini ve imgelerini kaybetmiştir. Warhol'un portrelerinde bu durum açıkça görülebilmiştir. Figürleri insani olmamakla birlikte robotumsu bir şekilde günlük yaşamdaki halleriyle resimlenmiştir. Ona göre insanlar toplumsal kimliklerinden ibarettir. Kişi olarak varlık gösterememişlerdir. Toplumda bir yere sahiptirler. Toplumsal rolleri dışında insani yönleri yoktur ve boşluktan ibarettirler. Warhol onlar gibi içsel bir yaşam sürdürmemiştir. İçsel yaşama değer vermez o yaşamı anlamsız görmüştür. Warhol'un figürleri günlük yaşamdan yalıtılmış, eleştirel bilinçten yoksun oldukları için, onlarda manevilik ve duygusallık görülmemiştir. Warhol'un resimlerinde eleştirel bilinç olmadığı için onlar insanlaştırılamamıştır"'(Yayman Ataseven, 2017: $5)$.

Warhol'un tekrarlama ile aslında yaptığı travmanın ya da arzunun etkisini azaltmaktır. Toplum tarafından arzu nesnesine dönüştürülen sanatçıların portrelerinde yapmak istediği de budur. Bir fotoğrafa baktı̆̆ımızda travmaya neden olabilir, ancak o fotoğrafa ikinci defa baktığımızda etkisi azalacaktır. Warhol'un da ölüm ve arzu ile ilgili görsellerde tekrarlama yaparak yapmak istediği budur(Özdemir ve Koca, 2013).

Warhol, yaptığı bir açıklamada ‘bir makine olmak istiyorum' şeklinde bir açıklama yapmış ve sıkıcı şeylerini sevdiğini, bu nedenle tekrar unsurunu kullandığını söylemiştir. Warhol'da makineleşme imgenin anlamını ya da kimliği yok ederek ve serigrafiyi kullanarak çoğaltma tekniğiyle gerçekleşmektedir(Özdemir ve Koca, 2013).

Warhol, kişilik bakımından, az konuşan, içe kapalı, sadece yeraltı dünyasından kişilerle arkadaşlık kurabilen, yalnız yaşayan ve eşcinsel bir sanatçıdır. Bu kadar göz önünde olmasının yanı sıra özel hayatında çok yalnız bir insandır. Warhol'un bu kadar aykırı bir görünüme sahip olmasının bir nedeni de 24 yaşında dökülen saçlarının yerine peruk takmasıdır. $\mathrm{Bu}$ peruk gridir ve yapaylığı oldukça belirgindir(Ötgün, 1995). Ayrıca, kendi görüntüsüyle barışıl bir birey değildir. Defalarca estetik yaptırmıştır(Kıvanç, 2014). Eşcinsel olması ile ilgili duyguları sanatında da yer yer kendisini göstermiştir.

Resim: 3, Andy Warhol, 1980-81, Self-Portraits in Drag / DragOtoportre

(Demiral, 2018). 

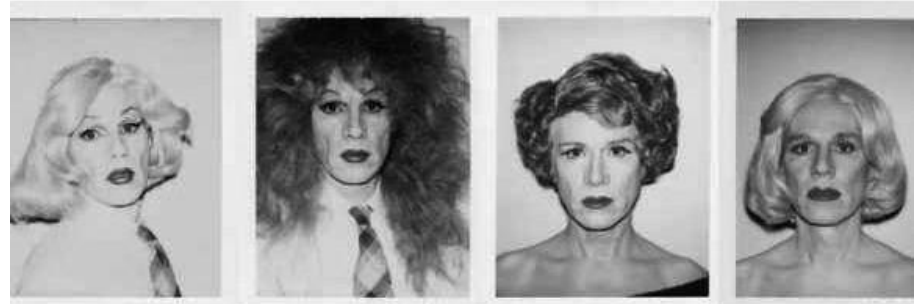

"Warhol, 32 Campbell adlı önemli çıkışından sonra aralarında M.Monroe, E. Presley ve E. Taylor gibi dünyaca meşhur süper starların bulunduğu seri-portreler yapmıştır. Sanatçının yaptığı bu işlerin dikkat çeken en önemli özellikleri, portrelerinin ikonik yapılarıyla buna uygun materyal, teknik ve sunum biçimleridir. 1964'de, Fabrika dediği atölyesinde gerçeğinden birebir kopyaladığı çok sayıdaki Brillo Kutuları ve Heinz Kutuları işlerini sergilediği etkinliğini gerçekleştiren Warhol 1980'li yıllarda dönemin toplumsal hayatının meşhur şahsiyetlerinin boya, mürekkep ve serigrafi baskıyı kombine ettiği tekniğini kullandığı portrelerini yaptı. Bu işlerin en önemli özelliği olarak öne çıkan tek-tiplik, seri ve tıpkıbasım izleniminin fiziki ve fiziköteci etkinin, sanatçı tarafından teamülden oluşturulmuş sanatsal duruşun gereği tercih edilmiş, bir teknik ve uygulama sonucu olduğu düşünülmektedir. Warhol felsefesi için gerekli olan teknik uygulama da mekanik, ardışık hızlı üretime elverişli olan modern serigrafi olmuştur”(Aydın, 2018: 229).

Warhol, 1968 yılında feminist yazar Valerie Solanas tarafindan, fabrika olarak adlandırdığı atölyesinde üç el ateş edilerek vurulmuştur. Bu üç kurşundan bir tanesi kalbine isabet ederek onu öldürmüş, kalp masajıyla hayata döndürülerek iki ay hastanede kalmasına neden olmuştur. 1969 yılında Interwiew dergisini kurmuş ve bu tarihten sonra portresini yaptığı her isim ünlü olmuştur(Kıvanç, 2014).

1970'li yıllar Warhol için daha sakin geçen y1llar olmuştur. Bu yıllarda, Michael Jackson, Mick Jagger, Liza Minelli gibi isimlerin portrelerini yaparak geçirdi. Ayrıca yine bu yıllarda, Andy Warhol'un felsefesi kitabını da yayınlamıştır. 1980'li yıllarda gücünün en üst noktasına ulaşan Warhol, Jean Michel Basquiat başta olmak üzere bir çok sanatçıya destek olmuştur. Andy Warhol, 22 Şubat 1987 tarihinde New York'ta hayatını kaybetmiştir(https://www.biyografi.net.tr/andy-warhol-kimdir/).

Gustave Courbet, 10 Ocak 1818 tarihinde Ornans'da doğmuştur. Ailesi demokrat çiftçi bir ailedir. Courbet'nin gençlik dönemi politik ve sosyal konularla ilgilenerek geçmiştir. Courbet'nin o dönem yaşadığı yer olan Contea bölgesi siyasi olayların olduğu bir bölgedir. İlk öğrenim hayatında isyankar ve disiplinsiz bir öğrenciydi ancak bu dönemde sanata olan yatkınlığı ortaya çıkmaya başlamıştır. 1837'de Besançon'daki Royal Kolejine başlayan Courbet'in dersleri pek parlak gitmemiştir. Ancak gelecekte bir yazar olacak olan Max Buchon ile arkadaşlığı iyi gitmektedir ve onun yazıları için litografi çalışmaları yapmaktadır. Daha sonra hukuk okumak için Paris'e giden Courbet burada bir resim atölyesine başlamıştır. Klasik resim anlayışını savunan hocası Flajoulot'nun düşüncelerine karşı gelmiş ve romantiklerin görüşlerini savunmuştur. Bu atölyeden ayrılarak, sanat tarihinden alınmış tabloları yapan Steuben'in atölyesine devam etmeye başlamıştır. Buranın ardından Desprez'in yanında çalışarak İsviçre Akademisine başlamıştır. Bu akademiye başladıktan sonra Louvre müzesine giderek ünlü eserleri kopya etmeye başlamıştır. 
1844 yılında açılacak olan Resmi sergide 'Siyah Köpekli Portre'si sergilenmeye uygun görülmüştür. Ancak 1847'li yıllarda teknik ve konu bakımından akademiye aykırı eserler ürettiği için tablolarına ilgi gösterilmemiştir(http://www.ressamlar.gen.tr/gustave-courbet-kimdir-hayatibiyografisi/).

Courbet, Hollanda ve İngiltere'ye uzun yolculuklardan sonra, 1848'de Paris'e yerleşmiştir. Burada, Courbet'nin atölyesine çok yakın yerlerde, yazar Champfleury ve Courbet başta olmak üzere, Baudelaire, Pienne Dupond, Murger gibi isimler Andler Pastahanesinde toplanarak Realizm'in hakkında tartışmalara girmişlerdir. Courbet, 1849'da 'Omans'da Bir Yemek Sonrası' eseriyle altın madalya kazanmış ve ün yapmıştır. 1855 'de ise Realizm'in öncüsü olarak kabul edilmiştir ve 70 'de Fransız hükümet nişanı verilmeye layık görülmüş ancak cumhuriyetçi görüşü savundukları için bu nişanı kabul etmemiştir. Aynı yıl Milletlerarası Sergi için jüri tarafindan on bir eseri seçilmiştir. Courbet, ayrıca Paris'te kişisel bir sergi de açmıştır(http://www.ressamlar.gen.tr/gustave-courbet-kimdir-hayati-biyografisi/).

Courbet bu açtığı sergilerin ardından, Realizm konusunda direnişi konusunda toplumun beğenisine boyun eğmek zorunda kalmış ve doğadan aldığı konulara yönlenmeye başlamıştır. Bu Courbet'in Realizm'den Doğalcılığa geçişine neden olmuştur. Bu dönem, çokça nü kadın, deniz manzarası ve av sahneleri çalışmıştır. 1867 yılında ikinci kişisel sergisini açmışıır. 1870'de Fransa Almanya savaşında Louvre müzesinde sayım görevlisi seçilmiştir. İmparatorun heykelini taşıyan sütunun üstüne Invalides'i koymayı önerince yargılanan Courbet tazminat ödemek zorunda kalarak tüm mal varlığını kaybetmiștir ve resimlerini satmak zorunda kalmıştır. (http://www.ressamlar.gen.tr/gustave-courbet-kimdir-hayati-biyografisi/).

Courbet, egemenlere karşı tavır sergileyerek, Paris’te devrimcilerin tarafinda olmuştur ve sanat işlerinden sorumlu olarak Sanat Birliği başkanlığına tayin edilmiştir. Özgür düşünceyi hayatının ve sanatının odak noktası yapan Courbet, sanatın piyasalaşmasına ve Burjuvanın sanatı yönetmesine olan tepkilerini resimleriyle ortaya koymaktadır. Courbet'nin bu eleştirileri, hükümet tarafından cezalandırılır ve resimlerine yasaklama getirilir. Bu nedenle, 70'de sanatın özgür ve sansürsüz olmasını savunan bildiriler yayınlamaya başlar(Bozdağ, 2015).

"Bu dönemde dile getirilen eşitlik ve özgürlük söylemleri hayata geçirilememiştir ancak Fransız İhtilali ile birlikte, insanlar arasındaki eşitsizliğin sebepleri sorgulanmaya başlanır. İhtilalden sonra yaşanan gelişmeler ve arkasından gelen sanayi devrimi eşitliği sağlayamadığı daha fazla eşitsizlik yaratan yeni bir yaşam biçimi ortaya çıkarır. Endüstrileşmenin başlamasıyla ortaya çıkan piyasalaşma, liberal ekonominin önünü açar. Marks ekonomi politiği teorisiyle sosyalizmi ortaya atar, sosyalizm liberalizm ile çatışmaya başlar. Piyasalaşma, kendisini sanat alanında da gösterir, piyasalaşmayı eleştiren ilk resimler bu dönemde yapılmaya başlanır. Courbet, "sanatçının atölyesi" adlı tablosu ile sanatın piyasalaşmasını eleştiren ilk ressam olur. Tablonun solunda sıradan dünya, sağında ise sanat dünyasının koleksiyonerleri ve sanat tacirleri temsil edilir. Tablonun ortasında yer alan sanatçı iki taraf arasındadır, kendisini anarşist olarak tanımlayan ve "mülkiyet hırsızlıktır" sözünün sahibi, felsefeci Proudhon'un da yer aldığı bu resim toplumsallı̆̆ı önemini 
vurgulayan sermayeye karşı eleştiri getiren önemli bir yapıttıı”(Bozdağ, 2015: 103).

Resim: 4, Gustave Courbet; Ressamın Atölyesi, 1855

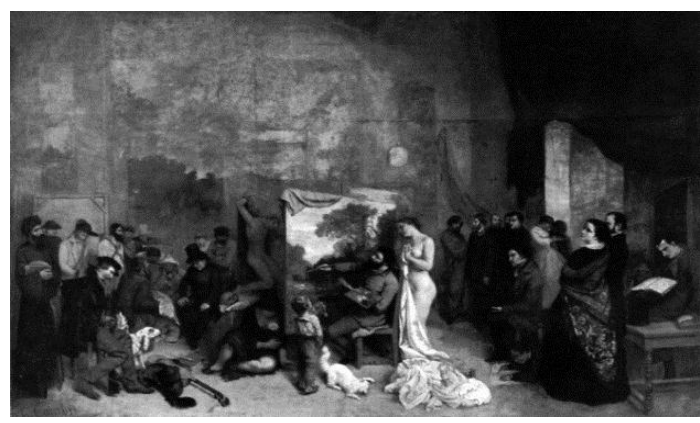

Courbet, bir süre sonra İsviçre'de La- Tourde-Perlz'e kaçmıştır. Bu süreçte kız kardeşi ve çocuğunu kaybetmesi onda derin travmalara neden olmuştur. 31 Aralık 1877 'de ise siroz hastalığından hayata veda etmiştir (http://www.ressamlar.gen.tr/gustave-courbet-kimdir-hayati-biyografisi/).

\section{Otobiyografik Sanatsal Anlatımda Bellek Otoportreleri ve Özne- Anti} Özne ve Benleşme-Ötekileşme Kavramları Arasındaki İlişşi

Otobiyografik ya da biyografik olarak ortaya konulan aslında çalışmalar, geçmişe yönelik bir benliğin ortaya koyulmasıdır. Benlik, hem geçmişin öne çıkartılmasıyla hem de olayların içinde anlatılarak, Ancak iki şekilde de belli bir izleyici kitlesi üzerinde amaçlanan etkiyi oluşturmaya yönelik bir şekilde ortaya koyulmaktadır. Geçmişin kurgusuna benliğin kurgusu dâhil edilir ya da daha doğrusu ikisi birlikte tekrar ortaya koyulmaktadır. Geçmiş, artık rollerin oynandığı bir oyuna dönüşmektedir. Yazar, kronolojik olarak gerçeklik çerçevesinde, içeriğini kendisinin beklenti ve izlenimlerine göre belirlediği bir tiyatro oyununu kurmaktadır. Yazarın algısı ve yazarla ilişkisi bağlamında, bazı bireyler iyi, bazı bireyler kötü karaktere bürünmüştür ya da rol bile almayı hakketmemiştir(Meşe, 2012).

Otobiyografinin öncelikle sözcüğün anlamı incelenirse 'oto'nun(öz’ün) kimliğe, kendi bilincindeki ben'i işaret etmektedir. 'Bio' ise kişinin kendisinden başkasının olmayan yaşamının akışı anlamına gelmektedir. İki kavram birleştiğinde, bireyin kendi hayatıyla kurduğu ilişki anlamına gelmektedir. Grafi kelimesi ise anlama, kendi hayatıyla kurulan ilişkinin bilinçli ve zahmetli bir şekilde kurulması anlamını katmaktadır(Koruç, 2018).

Otobiyografiyi biyografiden ayıran nokta, anlatılan kişinin imza atan kişi ile aynı olmasıdır. Bu bağlamda, sanatçının yapıtında kendisini hem özne hem nesne olarak tanımlandırmalıdır. Bu çerçevede görsel sanatlara bakıldığında, sanatçının otoportre çalışmaları ya da yaşamsal öyküsünü sunmak adına yaptığı eserleri otobiyografik anlatım içeren çalışmalar olarak kabul edilebilir. Bu bağlamda, sanatta otobiyografik anlatımlar ilk olarak bireyin önem kazanmaya başlamasıyla birlikte Rönesans döneminde gerçekleşmiştir. Romantizm ile birlikte ise, sanatçılar duygularını esere yansıtarak, sanatçının kendilerini ve kendi öznel algılayışlarını ortaya koymuşlardır. 
Realizme gelindiğinde ise, sanatçı kendi benini ortaya koymasıyla birlikte, kendi ben'i dışında olanı yani öteki'yi de olduğu gibi yansıtma yoluna gitmiştir(Koruç, 2018).

Kendi ben'ini ortaya koymak adına bir çok otoportre ortaya koyan bir ressam ise Rembrandt van Rijn (1606-1669)dir. Yaşamı boyunca kendi bellek otoportrelerini yaparak kendi ben'ini tam anlamıyla ortaya koymuş ilk sanatçıdır. Rembrant'ın portreleriyle ilgili olarak izleyici karşısındaki ile yüz yüze gibidir. Bu Rembrant'ın kendi ben'ini doğru okuyabilmesi ile ilişkilidir(Koruç, 2018).

Resim: 5, Rembrandt van Rijn, Kendi portresi/ Self Portrait, 1669.

(Koruç, 2018).

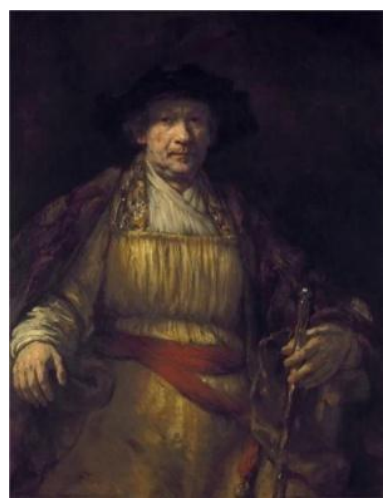

Fotoğrafın bulunmasıyla, sanatta meydana gelen gerçeklikle ilgili yaklaşımlar, sanatçıları yeni yaklaşımlara gitmeye mecbur bırakmıştır. Bu noktada, kendi otobiyografik eserlerini ortaya koyarken, içsel duyguları ortaya koymuşlardır. Yani görünen gerçeklik terk edilerek deneyimlenen bireysel gerçeklikler ortaya koyulmuştur. Örneğin, geçirdiği bunalımlardan kaynaklı, bellek otoportrelerinde bu bunalım oldukça çok hissedilen bir sanatçı Van Gogh'dur. Yaptığı otoportrelerde bunalımı renk ve çizgi ile hissettiren Van Gogh, kendi ben'ini başarılı bir şekilde ortaya koymaktadır(Koruç, 2018).

Resim: 6, Vincent Van Gogh, Sarg11 Kulaklı Otoportre, 1889.

(Koruç, 2018). 


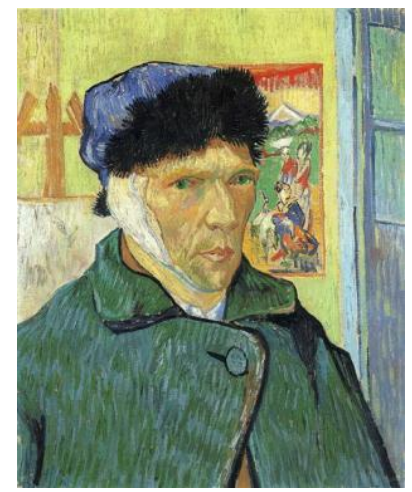

Modernizm ile gelișen teknolojiyle ilișkili olarak yeni malzemelerin sanat alanına girmesi, sanatçıların ifade şekillerinde değişikliğe neden olmuştur. Bu bağlamda yeni ve devrimci sanat anlayışlarıyla hem biçimsel, hem dedüşünsel olarak değişimler kendisini göstermiştir. sanatçıların bireysel yaratıcılığ Tüm bu yaşananlar otoportreyi etkilemiş ve otoportre türünü kullanan sanatçllar otoportrelerinde kişisel bellek içeriklerini farklı anlatım yollarıyla ortaya koymuşlardır. Buna, otobiyografik açıdan yaşamsal yolculuk yaparak kendi ben'ini ortaya koyan bir sanatçı olan Frida Kahlo örnek verilebilir(Koruç, 2018). Kahlo, bir trafik kazası geçirmesiyle, yürüyememesini, acılarla dolu hayatını içsel motivasyona çevirerek resimlerinde kullanmış ve izleyiciye kendi özyaşam öyküsünü sunmuştur. Ayrıca, yatalak kaldığı süreçte kendini ben'ini tavana bakılı aynaya bakarak ortaya koymuştur.

Resim: 7, FridaKahlo, Kırık Sütun, 1944.

(Koruç, 2018).

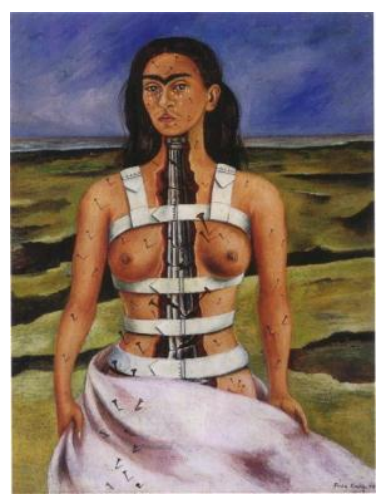

Modern dönemde ben ve öteki tartışmaları başlarken, Postmodern döneme geçişte bireyde ötekinin inşası daha da ön plana çıkarak sanat alanında daha çok kullanılır olmuştur. Bu bağlamda, 1rk, cinsiyet ve din gibi ötekileşmeye neden olan olgular tartışılmaya başlanarak sanatta işlenmiş ve öteki kimlik kazanmaya başlamıştır. Modern dönemden itibaren, ben'in yani kimliğin oluşmasını sağlayan öteki'dir. Sanatsal açıdan otobiyografik açıdan öteki'ni eserlerine aktaran yaklaşımlardan öne çıkan yaklaşım Feminizm'dir. Feminist sanatta kimlik ve benlik sorgulanırken, öteki'de ortaya koyulmuştur. 
Örneğin, Louise Bourgeois, kendi özyaşam öyküsünden yola çıkarak ortaya koyduğu eserlerinde kendi otobiyografik travmalarını ortaya koymaktadır. Eserleri feminist olarak kadının rolünü sorgulayan eserler olsa da, otobiyografik açıdan geçmiş yaşamıyla hesaplaşmalar yani geçmişinde öteki ya da ötekilerle hesaplaşmalar bulunmaktadır.

Resim: 8, Louise Bourgeois, Kadın Ev, 1947

(Koruç, 2018)

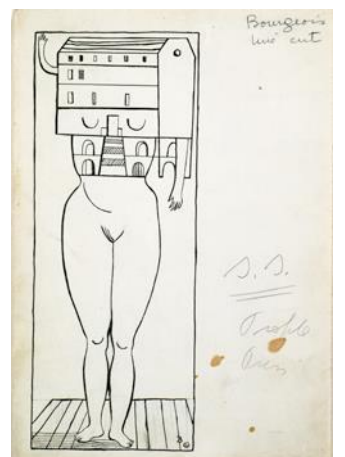

"Bourgeois, benliğini anılarının oluşturduğunu düşünür ve anılarını otobiyografik bir şekilde sanatının merkezine yerleştirmiş̧ir. Çocuklarıyla ilgili bir anne, dominant bir baba, iki kardeş, ve dadının olduğu bir ailede büyüyen Bourgeois, babası ve dadısı arasındaki özel ilişkiden dolayı taşıdığı çift taraflı güvensizlik duygusuyla bu duruma olan öfkesini birçok çalışmasında ele almıştır. Sanatçı zedelenen kimliği ve duyduğu öfkeyle başa çıkmanın yolunu özellikle heykele yönelerek bulmuş, ve geçmişini yeniden deneyimleyebileceği alanlar/mekânlar yaratmak için heykelin fiziksel/mekânsal olanaklarından yararlanmıştır”(Koruç, 2018: 37).

1970'li y1llarda Fransa'ya yerleşerek Feminist sanatın öncülerinden olan ve ben öteki kavramları üstüne çalışan Nil Yalter'in, eserleri, izleyici yani farklı ben'ler tarafindan farklı farklı yorumlanan eserlerdir. Bu eserlerde, kendi benliklerinden yola çıkarak ötekini ortaya koymaktadır. Eserde, bir erkek kadın çorabı giyerken, anlamsal açıdan eşcinselliğe yani öteki'ye göndermelerde bulunmaktadır(Aytekin ve Tokdil, 2016).

Resim: 9, Nil Yalter, Le Chevalierd'Eon, 1978, fotoğraf ve video.

(Aytekin ve Tokdil, 2016).

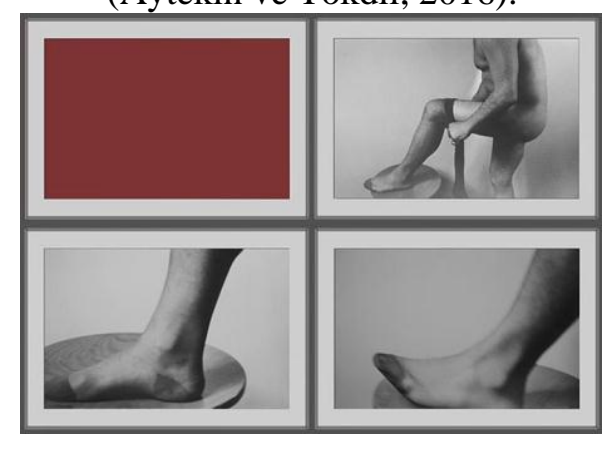


"Arthur Rimbaud'un "Ben bir başkasıdır" söylemi, Fransız feminist sanat akımının 1970'lerdeki temsilcilerinden olan Nil Yalter çalışmalarında farklı bir düşünsel boyuta taşınıyor ve "Hiç birşey bana ait değil" söylemine dönüşüyor. Onun çalışmalarında geçmişle bağlantılı unsurlar ön plana çıkarken, kendi bedeni, kendi ben'i olarak ortaya çıkıyor ve başkası kendi ben'i içerisinde görünüme çıkıyor. Farklı bedenler ve dolayısıyla farklı ben'ler iç içe geçiyor ve sanatçının eserlerinden tüm bu ben'lerin izleri görünür boyuta taşınıyor. Bu anlamda Rimbaud'un söyleminden farklı bir başkasılık söylemi ortaya çıkıyor; ben'ler birbiri içinde karışarak, çarpışarak, tek bir ben'i yaratmak yerine, yan yana ve kendi biçimsel, anlamsal özelliklerini geride bırakmadan bütünleşiyor"'(Aytekin ve Tokdil, 2016: 25).

Postmodern sanatta kendi ben'i üstünden öteki'ni ortaya koyan ve kendi bedeni ile ötekini ortaya koyma durumu söz konusudur. Bu konuda Cindy Cherman'ın 1970'li yılların sonlarında ortaya koyduğu fotoğraflar örnek olarak gösterilebilir. Cherman, kendi bedeni, yani kendi ben'i üstünden öteki' yi inşa ederek izleyiciye sunmaktadır. Bunu bir tiyatro sahnesindeki bir oyuncu gibi yaşarak ortaya koyması da benliği ile ötekiyi keşfetmesi açısından önemlidir. Öteki'nin keşfi, ben'in tanımlanmasında önemli rol oynamaktadır.

Resim: 10, Cindy Sherman,İsimsiz Film Kareleri, 1979

(Koruç, 2018).

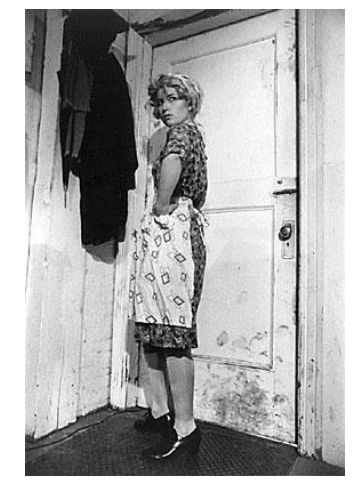

5. Karşıt Uçlarda İki Otobiyografik Sanatsal Anlatım (Özne-Anti Özne), Ben'e ve Öteki'ne Yolculuk İkiliği Bağlamında, Kendine Yaklaşma (Benleşme) ve Kendinden Uzaklaşma (Ötekileşme) Karşılaştırması: Andy Warhol ve Gustave Courbet Bellek Otoportreleri Çözümlemeleri

Resim: 11, Andy Warhol, Self Portrait, 1978

https://www.artsy.net/artwork/andy-warhol-self-portrait-1997 


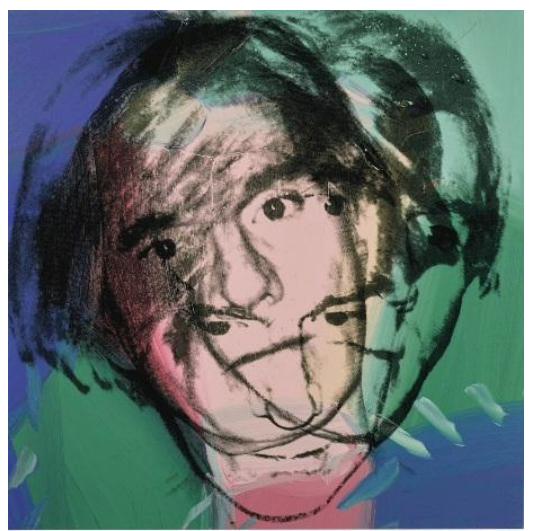

Her sanatçı ya da kuramcı mevcut söylemle belirsiz bir bağ içindedir. Bir bakıma, ondan alıntı yapmaktadır. Bu alıntıyı yaparken ironik ya da eleştirel de olabilir. Bu ortaya koyulan, Postmodern dönemde yeni değil, yalnızca neo olarak değerlendirilmektedir. İroni ise, çelişkiyi, uyuşmazlık biçimi alan zıtları barındıran çift katmanlı bir yapıdan olabilmektedir. Postmodern dönem sanatında eğitimli irdeleyici ve beklentisi olan izleyicinin tersine romantik sanatta izleyici önyargısızdır(Kuspit, 2000).

Sanat, içsel bir yolculuk yapmamıza aracı olmakta, ayrıca deneyimlediğimiz şeyde kaybolmamız için bu yolculuktan geri dönmemize de yardımcı olmaktadır. $\mathrm{Bu}$ perspektifle, eser izleyicinin derinliklerine ve sonra tekrar dışarıya çıkmaktadır. $\mathrm{Bu}$ bağlamda Baudrillard'ın da dediği gibi sanatçı "homo duplex" yani bölünmüş insan( içe doğru kendi psikolojisini, dışa doğru içinde bulunduğu toplumun psikolojisini ortaya koymaktadır. Ancak postmodernizm bu ikiliği kabul etmemektedir. Sanatçı içe doğru aktif bir dönüşümü başaramayan dişadönüktür. Buna en iyi örnek olarak, Warhol'un "bir makine olmak istiyorum" sözleri gösterilebilir. Bu sözlerle Warhol hem yaratıcı olmadığını itiraf etmekte, hem de kendi öznesine bir anti-özne yaratmaktadır(Kuspit, 2000).

Postmodern dönemde, sanatın yaratmasında meydana gelen bilinçaltının ortaya çıkışı düşüncesi yok olmaktadır. Ayrıca postmodenizmle öznel dünya düşüncesi de yok olmakta ve yerini öznel olmayan evren düşüncesi almaktadır. Ayrıca, Postmodern sanatta sahte bir benlik kurgusu söz konusudur. Warhol'un otoportreleri bu sahte benliği ortaya koymaktadır(Kuspit, 2000).

Her, yazar, sanatçı ve düşünür kendisi ile aynı düşüncede olanların birer benzeri düşüncesini ortaya koyarak ondan alıntı yapmakta ve ona ya da onlara ilişki ile bağlı kalmak durumundadır. Kendisi ile benzer düşüncelerin dışında, eleştirel bir tavır ortaya koyma ile ona karşıt bir düşünce geliştirilmiş denilebilir. Bu noktada, kendisi ile benzer olan düşünceler bağlamında kalanlar özne ile ilişki içerisindeki kapsama girenler olarak tanımlanmaktadır. Bu kapsam, ben'in ve biz'in karşılığı olarak kabul edilebilir. Ayrıca bu düşüncelere karşıt bir eleştiride bulunulduğunda ise, anti özne

Andy Warhol'un otoportresi, ben'leşme ya da öteki'leşme unsurlarının hangisini içerdiğinin tespiti amac1 ile otobiyografisi incelendiğinde, öncelikle, Warhol'un eşcinsel bir birey olması onu cinsel tercih bakımından toplum gözünde öteki 
bağlamına yerleştirmektedir. Sartre'ın da eserlerinde geçen eşcinsellikten tiksinti duyma hali, toplum tarafından ötekileştirilme haliyle benzemektedir. Ancak, daha önce de bahsedildiği üzere bu durum aslında kendisinden olmayana olan arzudan gelişen bir tepkidir ve Warhol otoportresinde sanki bununla dalga geçer gibidir. Ayrıca, yine onun otobiyografisinden yola çıkarak, "Ben asla parçalanmadım; çünkü hiçbir zaman bir bütün değildim” şeklinde açıklamaları, Ben ve öteki, varlığın parçalanması anlayışını ve varlıktaki metafizik birliği gözardı etmenin bir sonucu olarak, "ben"in ve başka bir "ben"in arasındaki ayrılığa işaret etmektedir. Bu da post-modern bellek otoportresindeki parçalanmayı açıklamaktadır.

Warhol, kendisini bir makine olmak istiyorum açıklamalarıyla aslında kendi benliğinin farkına vararak ötekileştirmek istemektedir ya da kendi ötekiliğinin farkına vararak bundan keyif almaktadır. Bu noktada Sartre'nin Varoluşçuluk felsefesi ile ilgili kitabındaki makine ile ilgili sözler akla gelmekte ve Warhol'un kendini makineye benzetmesine adeta eleştiri olarak algılanmaktadır.

"Makinenin üretimde kullanılması birtakım ters sonuçlar doğuruyor: Bir yandan, insan gitgide işlettiği makinenin egemenliği altına giriyor. Özünü, benliğini, bilincini, kişiliğini günden güne yitiriyor. Nerdeyse, dönen çarkın bir vidası haline geliyor, nesneleşiyor"(Sartre, 1985: 10). Bu benzeşim, Warhol'unda kendisini bir makineye benzeterek ve sanatsal açıdan makine şeklinde üretimler yapmasıyla kendi benliğini kaybetmesi ancak, kendi ötekiliğini ortaya koymak için yine kendisini kullanmas1 olarak okunabilir.

Ayrıca, otoportresi göz önünde bulundurulduğunda, kendisini dil çıkarırken betimlemiş, alaycı bir tavır sergilemektedir. Yani bu ötekileşmeden rahatsız değildir. Zaten, kişilik bakımında her zaman dikkatleri üstüne toplamayı başaran bir bireydir. Buna en büyük örnek, saçları döküldüğünde gri uzun bir peruk takmaya başlaması da gösterilebilir.

Warhol, kendi bedeniyle barışık olmadığı için, estetik müdahaleler yaptırmış ve farklı bir görüntüye bürünme isteği içinde olmuştur. $\mathrm{Bu}$ onun kendi ben'inin yolculuğuna çıkarak kendi ben'ini reddettiği ve öteki yolculuğunda keyif aldığ 1 şeklinde yorumlanabilir. Ayrıca Warhol'un estetik açıdan alaycılığı söz konusudur. Bu konuda EricFrom, "Bu sanatçının ve sanatın putudur. Put [insanın] kendi yaşam güçlerini yabancılaşmış, bir formda temsil eder”(From, 208; Kuspit, 2000: 50'deki alıntı) demektedir. Burada da bahsedildiği üzere bir yabancılaşma yani ötekileşme söz konusudur.

Warhol'un eserleri tüketim toplumuna yönelik eserlerdir. Bu tüketim toplumunda bireylerin kendine yabancılaşması yaygın görülmektedir. Bu bağlamda, Warhol'un da tüketim kültürüne ve tüketim toplumuna yönelik eserler üreterek kendinden uzaklaşması yani öteki'leşmesi söz konusudur(Kuspit, 2000).

Daha önce de belirtildiği üzere, ötekileşmenin en uç noktası kişilik parçalanmasıdır. Bireyin kendi benine ötekileşmesinin sonucunda parçalanmış kişiliklere bürünür. Warhol'da otoportresinde yarattığı parçalanmada, yaşadığı kişilik parçalanmasını, yani ötekiliği ne kadar uç noktada yaşadığını ortaya koymaktadır. 
Warhol'un ortaya koyduğu otoportrede, içerisinde bulunduğu dönem olan Postmodern dönemin de özelliği olan anti-özne tavrı okunmaktadır. Ayrıca bu antiözne biyografisinden elde edilen bilgilerle onun ötekiliğini açık şekilde bulgulanmaktadır.

Resim: 12, Gustave Courbet, Self Portrait (Desperate Man), 1844-45

https://www.wikidata.org/wiki/Q3222585

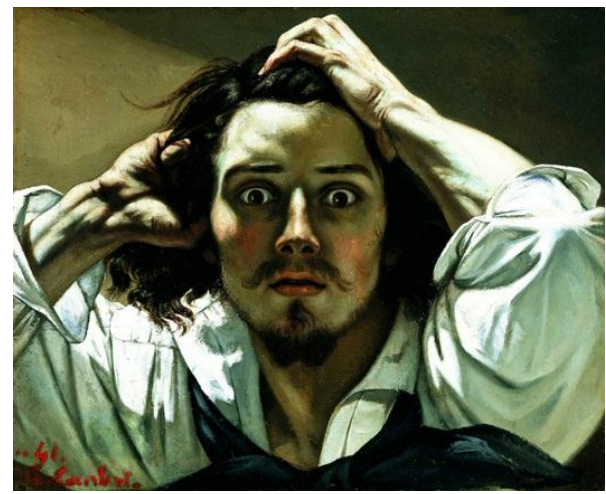

Gustave Courbet'nin otoportresi ve otobiyografisi incelendiğinde, ben'leşme, benliği ortaya koyma ve kendisini izleyice sunma isteği tespit edilmiştir. Courbet, siyasi yönü güçlü olan bir sanatçıdır. Kendi benliğini keşfetmiş olması nedeniyle layık görüldüğü sanatçı nişanını kabul etmemiştir. $\mathrm{Bu}$ onun, benliğinin kesin sınırlarını çizdiği anlamına gelmektedir. Zaten, Courbet, Ressamın Atölyesi adlı eserinde de (bkn Resim: 4) kendi benliği doğrultusunda betimlemelerde bulunarak eleştirel eserini ortaya koymuştur.

Self Portrait(Desperate Man) adlı eserinde de kendi benliğini olduğu gibi bir gerçeklik algısıyla otaya koyarak ben'leşme yolculuğu söz konusudur. Bu bellek otoportresinde, bakışları izleyiciyi sarsarak kendini anlatma çabası içinde yani benliği sunma isteği içindedir. Ayrıca, duruş kaygıyı ve endişeyi insana geçirmektedir. Bu yüz ifadesindeki kaygı, portreyi yaptığı dönemdeki siyasi karşıtlığ 1 ve resimlerine yasak getirilmesi üzerine yaşadığı zor durumlarla alakalıdır. $\mathrm{Bu}$ noktada Courbet, kendi otobiyografik öyküsünden yola çıkarak duygu ve düşüncelerini bu portre ile aktarmakta ve kendi ben'liğine olan yolculuğunu izleyiciye sunmaktadır.

“Courbet'nin tabloları kuşkusuz içtenliklidir. 1854'te yazdığ 1 bir mektupta şunları söylüyor: 'İlkelerimden k1l payı olsun sapmadan, vicdanıma bir an olsun yalan söylemeden, birisinin hoşuna gitmek veya kolay satabilmek için bir karış, tuval olsun boyamadan, yalnızca kendi sanatımla yaşamımı kazanacağımı umut ediyorum'. Courbet'nin kalıplaşmış, etkilere bilinçli olarak sırt çevirmesi ve dünyayı gördüğü gibi resmetme kararlığı, birçok sanatçıyı, alışılmış, yöntemlere karşı koyarak, sadece içlerinden gelen sanatsal sese kulak vermeye cesaretlenmiştir"(Gombrich, 2004: 511'den Dilaveroğlu, 2017: 93'deki alıntı).

Otobiyografilerinden yola çıkarak iki sanatçının da bellek otoportlerini ortaya koyma biçimleri farklı olduğu görülmektedir. Yani, sanatçıların otobiyografileri, kendi benlik ya da ötekilik yolculuğunu belirlemektedir. Bu bağlamda iki sanatçının 
otoportroleri kendi öz yaşam öykülerinden yola çıkarak çözümlendiğinde, Warhol'un otoportresinde, öteki yolculuğu, Courbet'in otoportresinde ben'leşme yolculuğu tespit edilmiştir.

Yukarıda bahsedildiği üzere, Courbet'nin bendi benliğini ortaya koymasının yanı sıra kendi öznesini de gerçekçi ve olduğu şekilde ortaya koyması söz konusudur. Ancak Warhol'da bu durum tam tersine kendi anti öznesini ortaya koyarak, ötekiliğini izleyiciye sunmakta ve bunu da kendi sözleriyle destekleyerek bir şekilde ortaya koymaktadır. Ayrıca, İki sanatçının otoportreleri karşılaştırıldığında, Warhol'un otoportresinde sahte bir benlik, Courbet'nin otoportresinde gerçek bir benlik ortaya koyulmaktadır.

\section{Sonuç;}

Bellek her zaman geçmişten bugüne bir akışı gösterir ve durağan değildir. Bunun sayesinde de insanın bilinçli varlığının öz'ünü, insan bilincini kuran da bellektir. $\mathrm{Bu}$ geçmişin 'şimdi' olarak geri çağrılmasıdır. Bellek otoportrelerinde de insanın bilinç ve bilinçaltı verilerinin yansımalarını bulabiliriz. Ben ve Öteki'ne yolculuk ikiliği bağlamında da iki ayrı örnek üzerinde kişisel bellekle ve dolayısı ile toplumsal bellekle de ilintili yönelimleri bulabilmekteyiz.

Ben ve öteki karşıtlığ psikolojik açıdan incelendiğinde, beni ben yapanın öteki, ötekiyi ise öteki yapanın ben olduğu bulgulanmıştır. Şöyle ki, ben ve öteki birbirinin varlığı ile benliklerini bulmaktadır. Lacan'ın da söylediği gibi, benliğin kurgusu ayna gerçekliğiyle gerçekleşmektedir. Felsefi açıdan ise ben ve öteki kavramları incelendiğinde 19. Yüzyıldan itibaren toplumda yaşanan bireyselleşme ile birlikte ben ve öteki konusuna yaklaşımlar özellikle Varoluş̧̧u düşünürler tarafından da oldukça irdelenmiş ve çeşitli görüşler ortaya koyulduğu bulgulanmıştır.

$\mathrm{Bu}$ bağlamda, örnekleme alınan Gustave Courbet ve Andy Warhol bellek otoportrelerinde ben'leşme ve Öteki'leşme unsurlarını doğru okuyabilmek adına sanatçıların otobiyografileri incelenerek Andy Warhol'un kişisel yaşamı, cinsel tercihi, düşünceleri ve yaşadığı olaylardan yola çıkarak otoportresinde kendisini betimlemesinden yola çıkarak ötekileşme, Gustave Courbet'nin kişisel yaşamı, siyasal görüşleri, başkaldırıları, otoportresinde kendisini betimleme biçiminde ise ben'leşme yani kendi benini ortaya koyma bulgulanmıştır.

\section{Kaynakça}

Apaydın, Ebru (2006). Levinas Felsefesinde Öznelik ve Öteki Problemi. Yayınlanmamış Yüksek Lisans Tezi. Ankara Üniversitesi Sosyal Bilimler Enstitüsü. Ankara

Aydın, Abdul Samet (2018). Çağdaş Baskı Resmi Üzerinden Güncellenen Bazı Eski Resmetme Teknikleri-Münhasır Sanatsal Yaklaşım Etkileşimine Bir 
Örnek Olarak Andy Warhol. Mehmet Akif Ersoy Üniversitesi Sosyal Bilimler Dergisi. Say1:24. Burdur. S:223-235.

Aytekin, Cemile Arzu ve Tokdil, Ezgi (2016). Düşünce Sistemlerinde Ben ve Başkası Problemi, Arthur Rimbaud ve Sanatta Ötekilik Üzerine. İdil Dergisi. Say1: 28. S: 17-30.

Aytekin, Cemile Arzu (2018) D.E.Ü Eğitim Bililimleri Enstitüsü Doktora Programı. Görsel Sanatlarda Dışavurumcu Anlatımda Otobiyografi Dersi Ders Notlar1.

Başer, Doğa (2011). Zygmunt Bauman'da Müphemlik ve Toplumsal Yaşam. Yayınlanmamış Yüksek Lisans Tezi. Afyon Kocatepe Üniversitesi Sosyal Bilimler Enstitüsü.

Bozbağ, Lütfiye (2015). Çağdaş Sanat ve Siyaset Dönüşümüne Yeniden Bakmak Politikanın Estetize Hali. Eğitim Bilim Toplum Dergisi. Cilt:13. Sayı:52. Ankara. 94-127.

Büyüktuncay, Mehmet (2014). Otobiyografi ve Paul Ricoeur: Tarihsel Anlatıda Zamanın Biçimlendirilmesi. CBÜ Sosyal Bilimler Dergisi. Say1: 1. Manisa. Sf:1-19.

Çelebi, Vedat (2008). S. Kierkegaard ve J. P. Sartre'ın Varoluşçuluk Anlayışınlarının Karşılaştırılması. Yayınlanmamış Yüksek Lisans Tezi. Pamukkale Üniversitesi Sosyal Bilimler Enstitüsü.

Demiral, Akın (2018). Queer Teori Ve Sanat; Sanatın Queer Hali. Hacettepe Üniversitesi Güzel Sanatlar Fakültesi 12. Ulusal Sanat Sempozyumu Değişen Paradigmalar ve Sanatta Sınır Deneyimler/ 26-27 Nisan 2018 Ankara.

Dursun, Çiler (2004). Hegel'de Kendilik Bilinci ve Öteki İçindeki Yolculuk. DoğuBat1 Düşünce Dergisi. Sayı: 7. İstanbul. Sf:182-188.

İspir, Naci ve Küçükalkan, Gülhanım (2013). "Ben” ve "Öteki” İlişkisinde İnsan ve Diğerleri. Atatürk İletişim Dergisi. Sayı: 5. Erzurum. Sf: 1-10.

Karaduman, Sibel (2010). Modernizmden Postmodernizme Kimliğin Yapısal Dönüşümü. Journal of Yasar University Dergisi. 17(5) İzmir. sf: 28862899.

Kıvanç, Mehmet (2014). Plastik Sanatlarda Özgüvenin Resme Yansıması. Yayınlanmamış Yüksek Lisans Tezi. İstanbul Arel Üniversitesi Sosyal Bilimler Enstitüsü. İstanbul.

Koruç, Esra (2018). Günümüz Sanatında Otobiyografik Anlatılar. Yayınlanmamış Yüksek Lisans Tezi. Hacettepe Üniversitesi Güzel Sanatlar Enstitüsü. Ankara.

Kuspit, Donald (2000). Semiyotik Anti- Özne. Güney Kaliforniya Üniversitesi, Güzel Sanatlar Fakültesi 4,6 ve 10 Nisan 2000'de verilen konferans. Çev: Ahmet Feyzi Korur. 
Layıkel, Şehnaz (2006). Sanat Yapıtı Üretim Sürecinde Öteki İle İlişki.

Yayınlanmamış Yüksek Lisans Tezi. Yıldız Teknik Üniversitesi Sosyal

Bilimler Enstitüsü. İstanbul.

Meşe, İlknur (2012). İki Kurgusal Metin Olarak Otobiyografi ve Tarih: Afet İnan Örneği. Fe Dergi: Feminist Eleştiri, Sayı: 1. Ankara. Sf: 28-41.

Ötgün, Cebrail (1995). Pop Sanat ve Andy Warhol. İçel-Yelken Dergisi Sayı: 5. Mersin. S: 78-92.

Özdemir, Fatih ve Koca, Binnaz (2013). Makine Olarak Andy Warhol. İdil Dergisi. Sayı: 6. Sf: 239-253.

Sartre, Jean Paul. (1985). Varoluşçuluk. İstanbul: Say Yayıncılık. Çeviri: Asım Bezirci. 8. Bask1.

Şahin, Veysel (2010). Oğuz Atay’ın Anlatılarında Ben, Öteki ve Benlik. Türk Dili Dergisi. S:697. Sf: 23- 31.

Temizkan, Ömer (2011). Öteki Tartışmaları Çerçevesinde ZygmuntBauman'ın Öteki Yaklaşımı. Yayınlanmamış Yüksek Lisans Tezi. Cumhuriyet Üniversitesi Sosyal Bilimler Enstitüsü. Sivas.

Yayman Ataseven, Serpil (2017). Andy Warhol'un Resimlerinde Popüler Kültürün Etkisi. Karadeniz Sosyal Bilimler Dergisi, Sayı: 16. S: 288-297. 